\title{
GERMINATIVE POTENTIAL IN QUINOA (Chenopodium quinoa Willd.) SEEDS STORED UNDER COOL CONDITIONS
}

\section{POTENCIAL GERMINATIVO EN SEMILLAS DE QUINUA (Chenopodium quinoa Willd.) ALMACENADAS BAJO CONDICIONES DE FRÍO}

\author{
Gladys Romero $^{1 *}$, Angie Heredia ${ }^{2}$, Hans Nicolás Chaparro-Zambrano ${ }^{3}$
}

${ }^{1}$ Bióloga, M.Sc., Ph.D. Genética y Fitomejoramiento., Docente-investigador. Universidad de Ciencias Aplicadas y Ambientales U.D.C.A, Calle 222 No. 55-37, Bogotá D.C., e-mail: glromeroa@udca.edu.co, (iDhttps://orcid.org/0000-0001-93945174; ${ }^{2}$ Ing. Agrónomo, egresada Universidad de Ciencias Aplicadas y Ambientales U.D.C.A; ${ }^{3}$ Ing. Agrónomo M.Sc. Fisiología y Producción Vegetal, Docente-investigador. Universidad de Ciencias Aplicadas y Ambientales U.D.C.A, Calle 222 No. 55-37, Bogotá, D.C., e-mail: hchaparro@udca.edu.co, @iDhttps://orcid.org/0000-0002-4355-8050 *corresponding author: glromeroa@udca.edu.co

Rev. U.D.C.A Act. \& Div. Cient. 21(2):341-350, Julio-Diciembre 2018 https://doi.org/10.31910/rudca.v21.n2.2018.1076

Artículo de acceso abierto publicado por Revista U.D.C.A Actualidad \& Divulgación Científica bajo una licencia Creative Commons CC BY-NC 4.0

\begin{abstract}
Quinoa is a crop with high potential due to its nutritional properties, wide adaptation to edaphoclimatic conditions and genetic diversity. This research aimed at evaluating four accessions of quinoa (Chenopodium quinoa) seeds, as well as their viability and germination percentage after cold storage. Storage temperatures and time were $4-20,-80^{\circ} \mathrm{C}$ and 10 months, with evaluation every two months. Initial seed viability was lower than $71 \%$ for all accessions and moisture content $10 \%$. After storage, all accessions showed an increase in germination percentage. The accession with the greatest increase in terms of germination and the lowest moisture level $(10,66 \%)$ before treatments, was the Nariño cultivar. Quinoa seed showed a secondary dormancy because of adverse storage conditions, this was inferred from the better response in germination after cold storage treatment. On the other hand, quinoa loses its germinative potential in short periods of time when stored under environmental conditions, therefore, regarding its storage, cool conditions and seed moisture content near $10 \%$ are recommended.
\end{abstract}

Keywords: seed storage, viability, temperature, water content, germination percentage.

\section{RESUMEN}

La quinua es un cultivo con alto potencial, por sus propiedades nutricionales, adaptación a diferentes condiciones edafoclimáticas y diversidad genética. La presente investigación tuvo como objetivo evaluar la viabilidad y el porcentaje de germinación de semillas de quinua (Chenopodium quinoa), en cuatro accesiones, procedentes de cultivos tradicionales, posterior a un almacenamiento en condiciones de frío. Las temperaturas de almacenamiento fueron 4-20 y $-80^{\circ} \mathrm{C}$, durante un tiempo de diez meses, con periodos de evaluación cada dos meses. La viabilidad inicial de las semillas estuvo inferior al $71 \%$ para todas las accesiones y con humedad en semilla, cercana al $10 \%$. Posterior al almacenamiento, los resultados indicaron un incremento en el porcentaje de germinación, presentando una mejor respuesta el cultivar Nariño, caracterizada con un menor nivel de humedad (10,66\%), previo a los tratamientos. La semilla de quinua presenta dormancia secundaria frente a condiciones adversas en su almacenamiento, ya que, posterior al uso de frío, se presentó mejor respuesta en germinación. De otro lado, bajo almacenamiento en condiciones ambientales, la quinua pierde su potencial germinativo en cortos periodos de tiempos, por lo tanto, se recomienda su almacenamiento en condiciones de frío y con un contenido de humedad de la semilla cercana al $10 \%$. 
Palabras clave: almacenamiento de semillas, viabilidad, temperatura, contenido de agua, porcentaje de germinación

\section{INTRODUCTION}

Quinoa (Chenopodium quinoa Willd.) is a plant of the Amaranthaceae family that grows mainly in the Andean region, which is the center of origin of the species (Apaza et al. 2013). Quinoa grains have a high nutritional value due to its ideal balance of essentials amino acids, fatty acids, content of vitamins and minerals such as iron and calcium (Muñoz \& Acevedo, 2002). Quinoa is qualified as a functional food (Filho et al. 2017; Abugoch, 2009) because its nutritional quality is superior to other grains like rice and wheat (Vilcacundo \& Hernández, 2017; Navruz-Varli \& Sanlier, 2016). According to the United Nations Food and Agriculture Organization FAO (2010), Quinoa is a promissory crop by reason of its multiples uses, high adaptability to a wide range of climatic conditions, tolerance to abiotic factors and high genetic diversity (Montoya et al. 2005; Mújica \& Jacobsen, 2006; Vargas et al. 2015). However, Quinoa seed quality is influenced by the low germination rate and reduced vigor; seeds lose viability more rapidly than cereals because of the porosity in the integument, which allows a seed to easily gain or lose moisture and may initiate germination in the panicle (Spehar \& Santos, 2002).

Quinoa seeds have an orthodox behavior, because they naturally dehydrate up to a water content in equilibrium with the environment that implies a subsequent artificial drought tolerance up to about 5\% water content without losing viability (Ellis et al. 1990). In this type of plant, seed cells get dehydrated due to losses of vacuolar water, supplied from their mother plant to seed during the maturity process, which helps keep viability and storage potential (Magnitskiy \& Plaza, 2007). Conservation techniques of orthodox seed require a minimum physiological activity (Calle et al. 2010). However, some non-enzymatic events occur in low water contents, this reaction leads to seed aging, producing an alteration on functional proteins that weakens the metabolic system and limits the capacity to defend itself from free radical damage and to repair damages throughout the germination process (Castellión et al. 2010).

The moisture content is a relevant factor that can affect the rate of damaging and aging reactions during seed storage period (Castellión et al. 2010). One of the conditions that need to be met in Quinoa seeds storing is having about $10 \%$ of moisture to increase longevity (Ellis et al. 1988). Under unsuitable conditions of relative humidity $75-80 \%$ and temperatures of $10-20^{\circ} \mathrm{C}$ respectively, seeds lose viability in a short period of time (Ellis et al. 1993). Storage conditions can influence the dormancy pattern output and seed longevity along with seed variety from contrasting environments (Strenske et al. 2017; Castellión et al. 2010).

The first long-term seed conservation was carried out in the Bolivian C. quinoa germplasm bank, with the conservation of 247 accessions of quinoa (Rojas et al. 2003). According to the FAO (2010), ex situ conservation of 16,263 accessions of quinoa and wild relatives was carried out in 59 seed germplasm banks in 30 countries around the world (Rojas et al. 2013). Storage and conservation of germplasm as well as commercial seed production, require adequate viability prediction and monitoring (Ceccato et al. 2013).

As a reproductive organ of plants, seed has a vital role to play in the propagation and perpetuation of the species; likewise as a source of food for animals and humankind. In agricultural production, the seed quality is essential for crop success. This quality depends on, among other features, its genetic, physiological, health and physical characteristics (Doria, 2010).

According to Antuna et al. (2003), physiological quality includes structures and processes that allow the seed to maintain high rates of viability; this quality component must be checked before sowing or storage. Seed storage allows distribution in time and space. Conditions associated with seed quality like germination and viability must be preserved. Water content, temperature and oxygen are fundamental factors in the control of seed longevity (Roberts \& Ellis, 1989).

Considering the limited information on quinoa seed viability stored under different temperatures, the objective of this research was to determine the effect of cold storage in the viability of four accessions of Ch. Quinoa from different origin.

\section{MATERIAL AND METHODS}

The evaluation was developed during the years 2014 - 2015 at the Universidad de Ciencias Aplicadas y Ambientales U.D.C.A, in the agrarian unit 'El Remanso' (4'47'57.98" N $74^{\circ} 2^{\prime} 47.17$ " W, altitude 2.560 m.a.s.l) located in the savannah north of Bogotá.

Seed material was obtained from four accessions of Chenopodium quinoa. Three of them were from production zones of Colombia: Nariño, Boyacá and Bogotá (Usme); the fourth one was a Bolivian accession donated by the Jardín Botánico de Bogotá in the meeting "Traveling Exhibition of Quinoa - Colombia 2014". The time after seeds are stored is referred to as post-harvest period, which corresponded to one month for Nariño and three months for the other accessions. 
A completely random design was used in a 3x4x2 factorial arrangement (temperature, accession and substrate, respectively) with three repetitions and an experimental unit consisting of one hundred seeds. Germination assessment was carried out in greenhouse, using as commercial peat soil substrate and soil enriched with organic matter, in trays of 128 alveoli.

To identify the initial state of the seeds, physiological tests of moisture content, imbibition and viability were performed. The initial moisture (fresh weight percentage FW\%) of the seeds was determined by its constant dry weight after drying. For this purpose, the samples were dried in an oven at a temperature of $103^{\circ} \mathrm{C}$, during $17 \mathrm{~h}$ as recommended by the ISTA (International Seed Testing Association).

The imbibition curve was estimated from $10 \mathrm{~g}$ of seed, with measures of weight every hour for six hours. The viability test was performed using the tetrazolium test technique in Petri dishes with tetrazolium chloride (2,3,5-triphenyl-2Htetrazolium chloride) at $1 \%$ and temperature of $30^{\circ} \mathrm{C}$ in a period of two hours. The seeds were observed by stereoscope and the one that presented homogeneous staining of the embryo (in line with the cotyledons and the radicle that surrounds the perisperm in the form of a ring) was defined as viable seed; according to the first two seeds of figure 1 .

The different accessions were stored for 10 months, at temperatures of $4,-20$ and $-80^{\circ} \mathrm{C}$, using hermetic bags, covered with aluminum foil to ensure a minimum gas exchange and absence of light, temperatures of seeds were maintained in a cooler and a freezer. Germination tests were carried out at 2, 4, 6, 8 and 10 months of conservation. Germination tests were carried out prior to storage (ambient conditions) at the beginning of the assay and after ten months under the same conditions (control).

Data were subjected to analysis of variance (ANOVA). Post hoc tests of means comparison were performed using Tukey's honestly significant difference (HSD). The analyses were performed with the R Core Team statistical package, 2015.

\section{RESULTS AND DISCUSSION}

The initial moisture content corresponded to 10.66, 11.59, 11.80 and $12.47 \%$ for the Nariño, Boyacá, Bogotá (Usme) and Bolivia accessions, respectively. The seed water content is a relevant factor that can affect the rate of damaging and aging during long time-storage (Justice \& Bass, 1978). An alternative to reduce deterioration and enhance longevity of orthodox seeds is decreasing water content and storage temperature.

The imbibition curve of the four accessions of quinoa (Figure 2) and the differentiation between germination phases I and II were observed. Phase I corresponds to the rapid increase in water absorption as shown from 0 to 5 hours with an exponential behavior of the curve, evidencing weight gain in the four accessions. The highest rate occurred after one hour of imbibing the seed. After five hours, the absorption of water decreases; thereafter, the weight begins to stabilize in the transition to phase II. In the second phase, Hartmann et al. (2011) showed that metabolism could be activated because of protein synthesis, carbohydrates and lipids; perisperm is the unique carbohydrate source, after emergence cotyledons develop chlorophyll and are efficient photosynthetic organs.

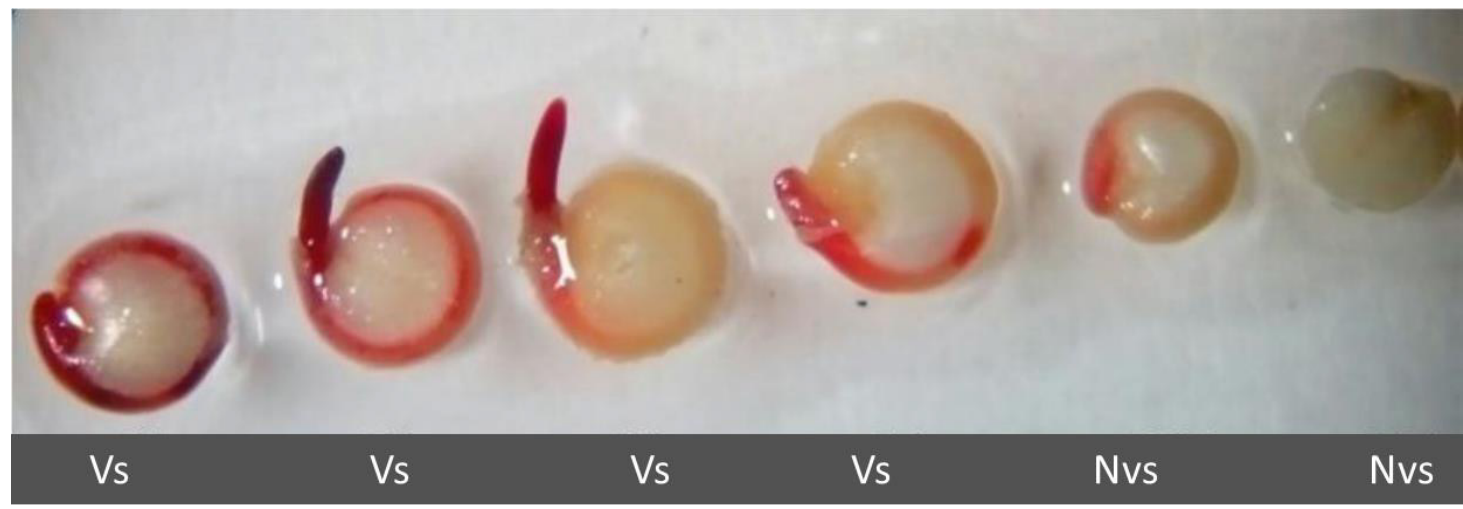

Vs: Viable seed; Nvs: non-viable seed.

Figure 1. Reddish stain of the embryo in the Nariño accession. Viability test by tetrazolium (2,3,5-triphenyl-2H-tetrazolium chloride) $1 \%$, in seeds of Chenopodium quinoa Willd. 


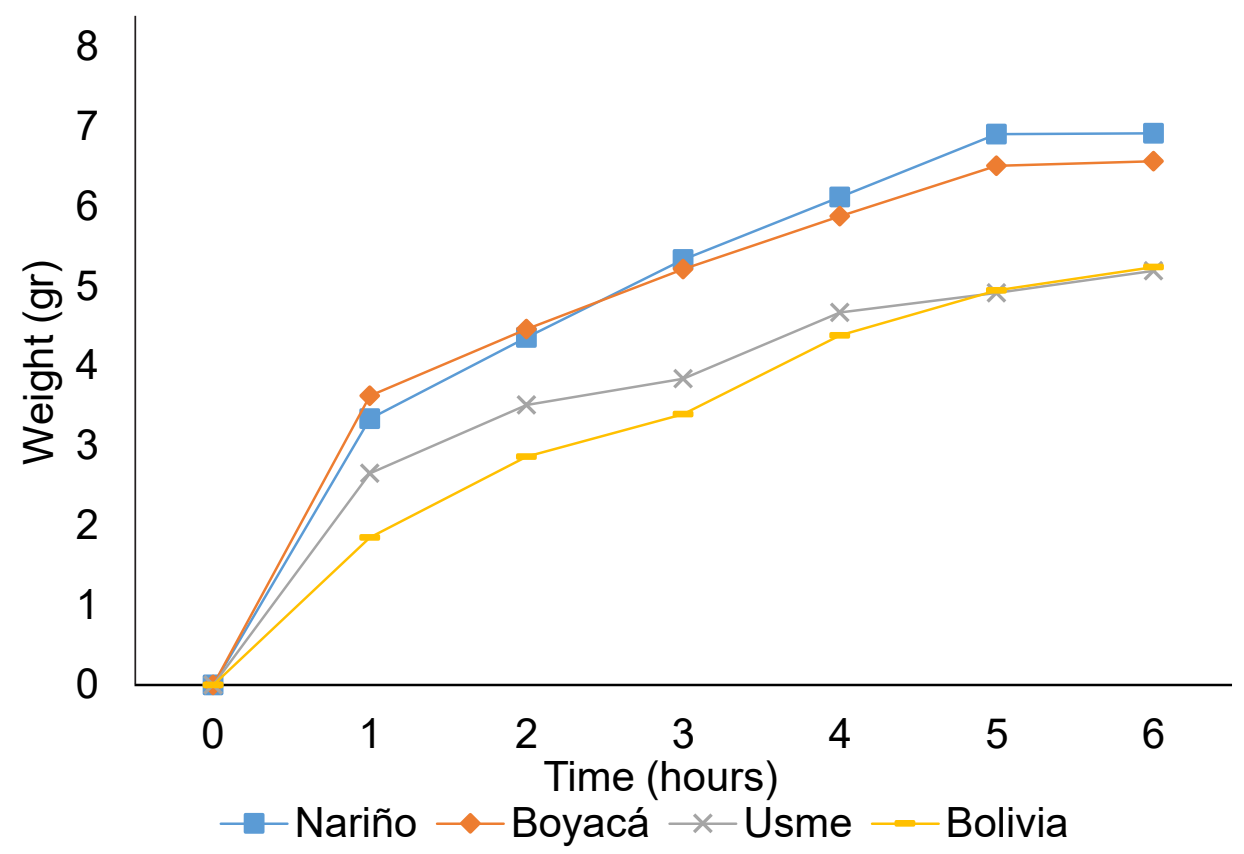

Figure 2. Imbibition curve of Chenopodium quinoa Willd. in accessions from Nariño, Boyacá, Bogotá (Usme), Bolivia.

Therefore, the nutrition is available for the embryo and it starts growing up (Rosa et al. 2009).

Quinoa seeds have a high and rapid permeability, under optimal physiological and environmental conditions, it has a high germinative potential. Depending on the environmental conditions, this aspect represents a risk, because the seed can germinate in pre-harvest period (Gubler et al. 2005; Kermode, 2005).

Regarding the viability quantification by the tetrazolium method, the accessions have shown percentages lower than $80 \%$. It is noteworthy that genetic and physiological quality of quinoa seed had a viability and germination rates close to $100 \%$ in the harvest. However, its loss of life and viability is faster compared to cereals due to the porosity in the integument, which allows it to gain or lose moisture easily (Spehar \& Santos, 2002).

In seed viability, the measures indicated that the accessions from Boyacá and Nariño reached 71 and 70\%; while the accessions from Bolivia and Usme (Bogotá) registered 55 and $10 \%$, respectively. The lower viability in the Bolivia and Bogotá (Usme) accessions can be attributed to post-harvest management conditions, genotype, seed provenance and prevailing conditions during seed development (GómezTejero et al. 2006). Castellión et al. (2010) obtained viabilities close to $100 \%$ under storage conditions at $-20^{\circ} \mathrm{C}$ and seed humidity content of $6 \%$. Nevertheless, in the present research seeds were studied in a post-harvest period of 1 to 3 months without specific storage conditions, seeds were acquired from growers in different zones, fresh seeds were not available, additionally, viability technique with tetrazolium sales, is subjective and not discriminate seed in dormancy.

The germinative potential -percentage of germination- for each accession of quinoa assessed at different storage temperatures, presented no significant differences within the assessment times (Table 1) during the period. Nevertheless, according to data in table 1 , the highest germination percentages occurred under storage temperatures of -20 and - $80^{\circ} \mathrm{C}$ (Figure 3). Walters et al. (2004) mention the different degrees of low temperatures that contribute to prolong seed's lifespan; this aspect depends on intrinsic properties, handling and harvest of seed. Moreover, pre-storage under higher temperatures had dramatic effects on longevity.

Furthermore, the effect of substrate had no significant differences, in contrast, it showed greater germinative power in commercial peat treatment. As regards interaction between substrates and accessions, there were significant differences registered in the second month of storage (figure 4a; $\mathrm{p}$-value: 4.8E-03) for cultivars of Bolivia and Boyacá, while for Nariño they happened in the sixth month (Figure 4b). 
Table 1. Germination percentage of four accessions of quinoa, under different storage temperatures and two substrates. Glass house, U.D.C.A.

\begin{tabular}{|c|c|c|c|c|c|c|c|}
\hline \multicolumn{8}{|c|}{ GERMINATION PERCENTAGE } \\
\hline \multirow{2}{*}{ Accession } & \multirow{2}{*}{$\begin{array}{l}\text { Sub- } \\
\text { strate }\end{array}$} & \multirow{2}{*}{ Temperature } & \multicolumn{5}{|c|}{ Storage time (month) } \\
\hline & & & 2 & 4 & 6 & 8 & 10 \\
\hline \multirow{6}{*}{ Nariño } & \multirow{3}{*}{ Peat } & $4^{\circ} \mathrm{C}$ & 17.00 abcd* & 18.33 abcd & $52.33 \mathrm{ab}$ & 51.33 abc & $56.33 \mathrm{abc}$ \\
\hline & & $(-) 20^{\circ} \mathrm{C}$ & $23.33 \mathrm{abc}$ & 25.33 abcd & 49.33 abcd & $\begin{array}{l}49.67 \\
\text { abcd }\end{array}$ & $59.67 \mathrm{ab}$ \\
\hline & & $(-) 80^{\circ} \mathrm{C}$ & 27.67 a & $31.67 \mathrm{ab}$ & 65.67 a & $68.00 \mathrm{a}$ & $69.00 \mathrm{a}$ \\
\hline & \multirow{3}{*}{ Soil } & $4^{\circ} \mathrm{C}$ & 17.67 abcd & 28.67 abc & 50.67 abc & $59.33 \mathrm{ab}$ & $58.33 \mathrm{ab}$ \\
\hline & & $(-) 20^{\circ} \mathrm{C}$ & $24.67 \mathrm{ab}$ & 21.67 abcd & 33.67 bcdef & $\begin{array}{l}49.00 \\
\text { abcd }\end{array}$ & $\begin{array}{l}49.67 \\
\text { abcd }\end{array}$ \\
\hline & & $(-) 80^{\circ} \mathrm{C}$ & 21.00 abcd & $33.33 \mathrm{a}$ & 45.33 abcde & $60.00 \mathrm{a}$ & $65.00 \mathrm{a}$ \\
\hline \multirow{6}{*}{ Boyacá } & \multirow{3}{*}{ Peat } & $4^{\circ} \mathrm{C}$ & $23.50 \mathrm{abc}$ & 19.33 abcd & $18.50 \mathbf{f}$ & $24.50 \mathrm{e}$ & $28.00 \mathrm{e}$ \\
\hline & & $(-) 20^{\circ} \mathrm{C}$ & 12.67 abcd & $16.33 \mathrm{~cd}$ & 28.00 def & 35.00 cde & $35.67 \mathrm{de}$ \\
\hline & & $(-) 80^{\circ} \mathrm{C}$ & 11.00 bcd & $12.67 \mathrm{~d}$ & 24.00 ef & $21.00 \mathrm{e}$ & $24.05 \mathrm{e}$ \\
\hline & \multirow{3}{*}{ Soil } & $4^{\circ} \mathrm{C}$ & 12.00 abcd & $18.00 \mathrm{bcd}$ & 24.67 ef & $29.00 \mathrm{de}$ & $32.00 \mathrm{de}$ \\
\hline & & (-) $20^{\circ} \mathrm{C}$ & 19.67 abcd & 22.67 abcd & 30.33 bcdef & 36.33 cde & $38.00 \mathrm{cde}$ \\
\hline & & $(-) 80^{\circ} \mathrm{C}$ & 8.33 bcd & 17.00 bcd & 31.67 bcdef & 36.00 cde & $37.67 \mathrm{cde}$ \\
\hline \multirow{6}{*}{$\begin{array}{l}\text { Bogotá } \\
\text { (Usme) }\end{array}$} & \multirow{3}{*}{ Peat } & $4^{\circ} \mathrm{C}$ & $11.00 \mathrm{bcd}$ & $17.33 \mathrm{bcd}$ & 23.67 ef & $32.67 \mathrm{cde}$ & $35.33 \mathrm{de}$ \\
\hline & & (-) $20^{\circ} \mathrm{C}$ & $7.67 \mathrm{~cd}$ & 24.67 abcd & 33.00 bcdef & $\begin{array}{l}38.00 \\
\text { bcde }\end{array}$ & $\begin{array}{l}42.00 \\
\text { bcde }\end{array}$ \\
\hline & & $(-) 80^{\circ} \mathrm{C}$ & 16.33 abcd & 25.00 abcd & 29.33 cdef & $35.67 \mathrm{cde}$ & $38.33 \mathrm{cde}$ \\
\hline & \multirow{3}{*}{ Soil } & $4^{\circ} \mathrm{C}$ & $8.00 \mathrm{~cd}$ & 18,00 bcd & 25,67 ef & 30,33 cde & $33,33 \mathrm{de}$ \\
\hline & & $(-) 20^{\circ} \mathrm{C}$ & 8,33 bcd & 19.00 abcd & 27.33 def & $31.67 \mathrm{cde}$ & $34.00 \mathrm{de}$ \\
\hline & & $(-) 80^{\circ} \mathrm{C}$ & 15.00 abcd & 19.67 abcd & 24.67 ef & 33.33 cde & $34.33 \mathrm{de}$ \\
\hline \multirow{6}{*}{ Bolivia } & \multirow{3}{*}{ Peat } & $4^{\circ} \mathrm{C}$ & 23.00 abc & 19.67 abcd & $18.33 \mathbf{f}$ & $19.67 \mathrm{e}$ & $22.67 \mathrm{e}$ \\
\hline & & (-) $20^{\circ} \mathrm{C}$ & 17.67 abcd & 18.67 abcd & $21.33 \mathrm{f}$ & $23.33 \mathrm{e}$ & $23.33 \mathrm{e}$ \\
\hline & & $(-) 80^{\circ} \mathrm{C}$ & 16.33 abcd & 17.67 bcd & $18.67 \mathbf{f}$ & $21.33 \mathrm{e}$ & $25.33 \mathrm{e}$ \\
\hline & \multirow{3}{*}{ Soil } & $4^{\circ} \mathrm{C}$ & $7.00 \mathrm{~cd}$ & $12.67 \mathrm{~d}$ & $16.67 \mathrm{f}$ & $18.67 \mathrm{e}$ & $22.33 \mathrm{e}$ \\
\hline & & $(-) 20^{\circ} \mathrm{C}$ & $7.33 \mathrm{~cd}$ & $10.67 \mathrm{~d}$ & $17.00 \mathrm{f}$ & $20.33 \mathrm{e}$ & $23.00 \mathrm{e}$ \\
\hline & & $(-) 80^{\circ} \mathrm{C}$ & $5.00 \mathrm{~d}$ & $15.00 \mathrm{~cd}$ & $18.33 \mathrm{f}$ & 20.00 e & $24.67 \mathrm{e}$ \\
\hline
\end{tabular}

** Means followed by the same letter within the columns have no significant differences (Tukey $\leq 0.05)$. 


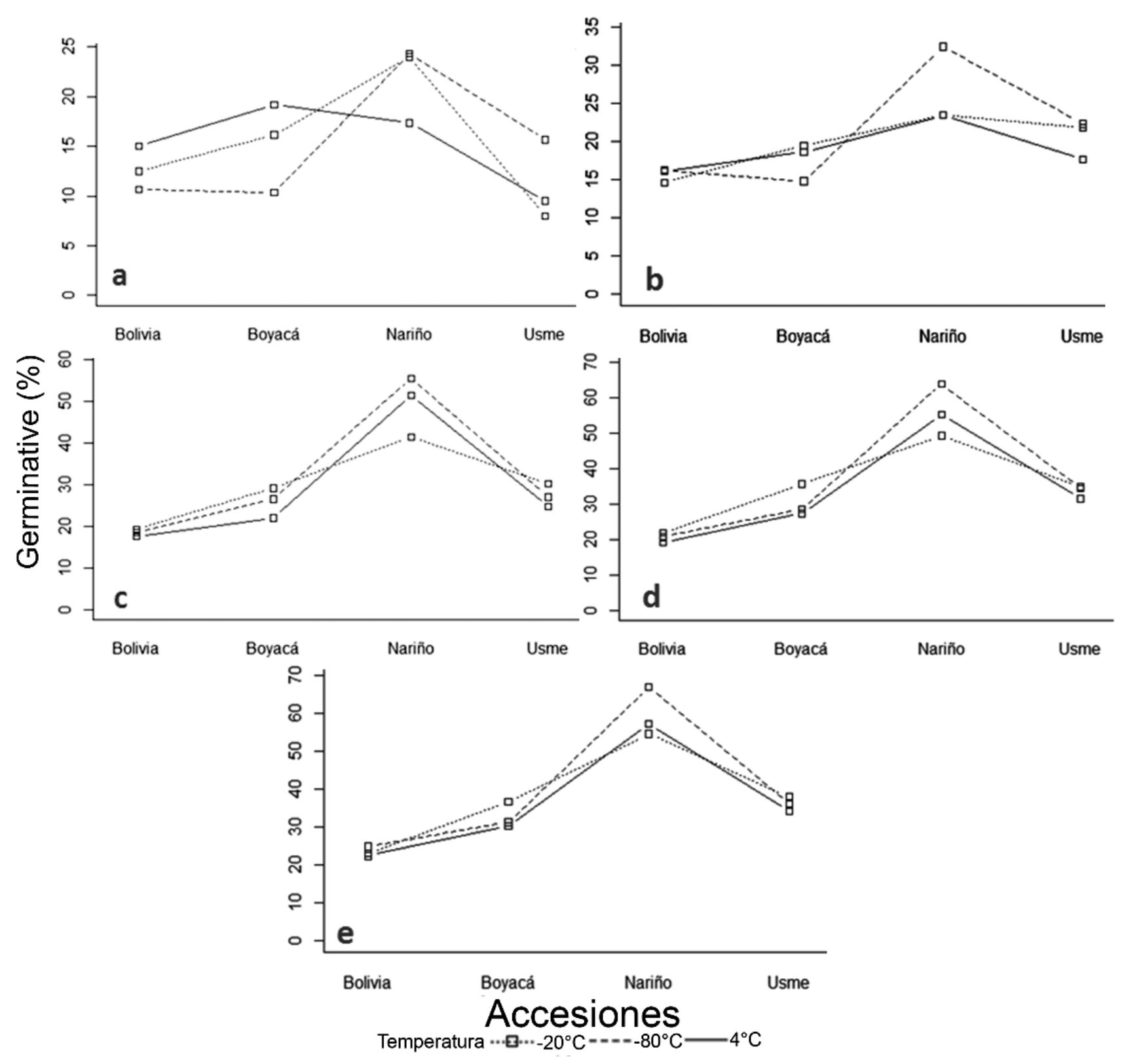

Figure 3. Germination percentage in four accessions of quinoa (Boyacá, Bolivia, Nariño, Bogotá-Usme) with respect to the temperature treatment in five storage times (months 2, 4, 6, 8 and 10), respectively figures from a to $\mathrm{d}$. 


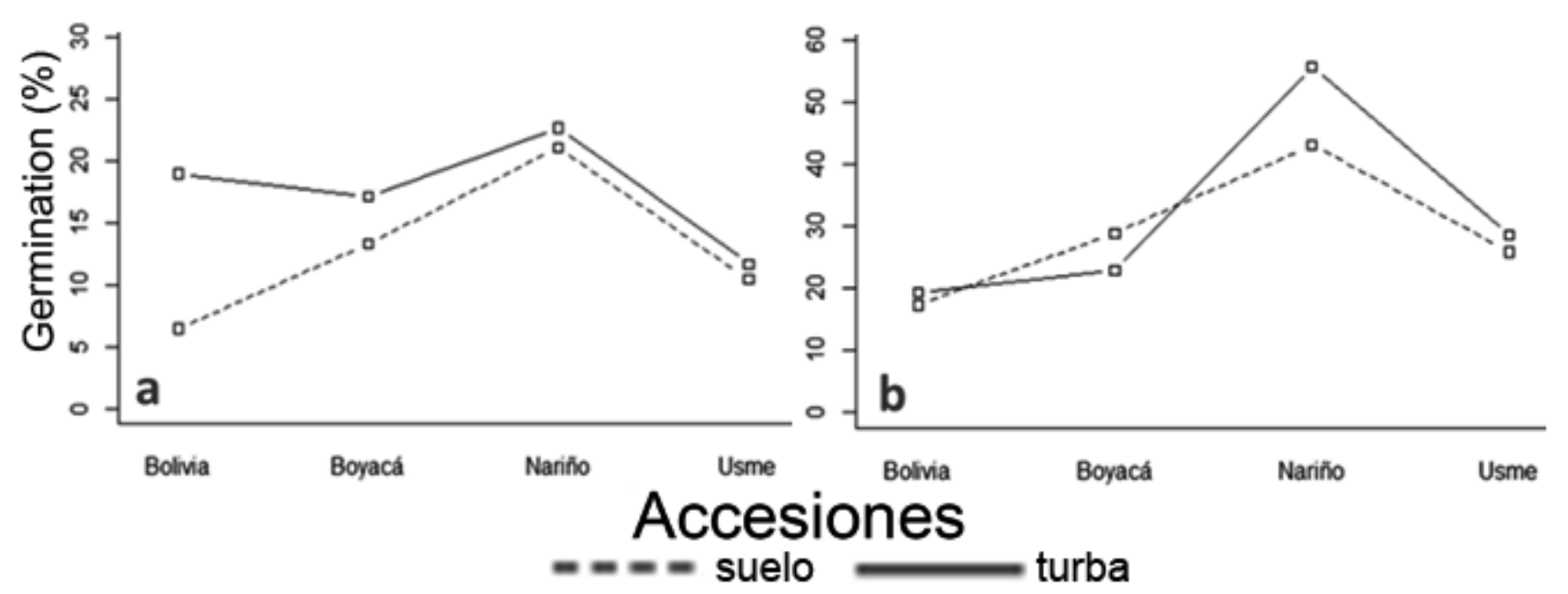

Figure 4. Accession and substrate interaction on percentage of quinoa germination. a) month two of storage; b) month six of storage.

Percentage of germination showed notable differences between accessions over the months of evaluation. The Nariño accession obtained the greatest response. This high percentage of germination can be attributed to the short time of harvest, which indicates its high seed viability, according to tetrazolium test. In addition, the Nariño accession registered the lowest seed moisture content (10.66\%). Moisture content close to $10 \%$ was reported as an optimum condition for storing orthodox seeds.

The accessions of quinoa were measured twice. First, before starting the assay, and second, ten months later without storage (control) at room temperature under laboratory conditions (Figure 5). The losses of germinative potential were evidenced for all accessions. A similar behavior was found on the two substrates evaluated. Results were concordant with those presented by Castellión et al. (2010), who indicated losses in viability and germination in quinoa seeds stored under ambient conditions, evidencing different responses between cultivars. The foregoing was associated with the origin of the cultivar, genotype, and physiological harvest conditions.

Accessions showed a progressive increase in the percentage of germination over the months of cold storage. This indicates that temperature changes contribute to breaking the dormancy in quinoa seeds. According to Ceccato et al. (2011), the lack of dormancy in quinoa cultivars highlights the importance of determining the effect of environmental and physiological factors over changes in the dormancy levels of quinoa seeds during its development, maturation and post-harvest storage. Similar works in sesame (Almeida et al. 1999), cucumber (Torres et al. 2002) and passion fruit (Catunda Aragão et al. 2003), registered an increase in germination after some months of storage.

Quinoa is a seed featuring orthodox behavior, which enables its storage under physiological conditions (maturation, water content) and an appropriate environment. According to the results of this study, it is recommended to keep under cool conditions seeds intended for establishing new crops. Viability is progressively affected by the post-harvest period or the time that passes without adequate storage conditions. Furthermore, seeds destined to germplasm banks are recommended to be conserved at temperatures equal to or lower than $-20^{\circ} \mathrm{C}$. Results for $4^{\circ} \mathrm{C}$ were not significant, however there were better responses to lower temperatures.

Funding: This study was funded by the University of Applied and Environmental Sciences U.D.C.A. Conflicts of interest: The manuscript was prepared and reviewed by all of the authors who declared having no conflict of interest that jeopardizes the validity of the results presented. 


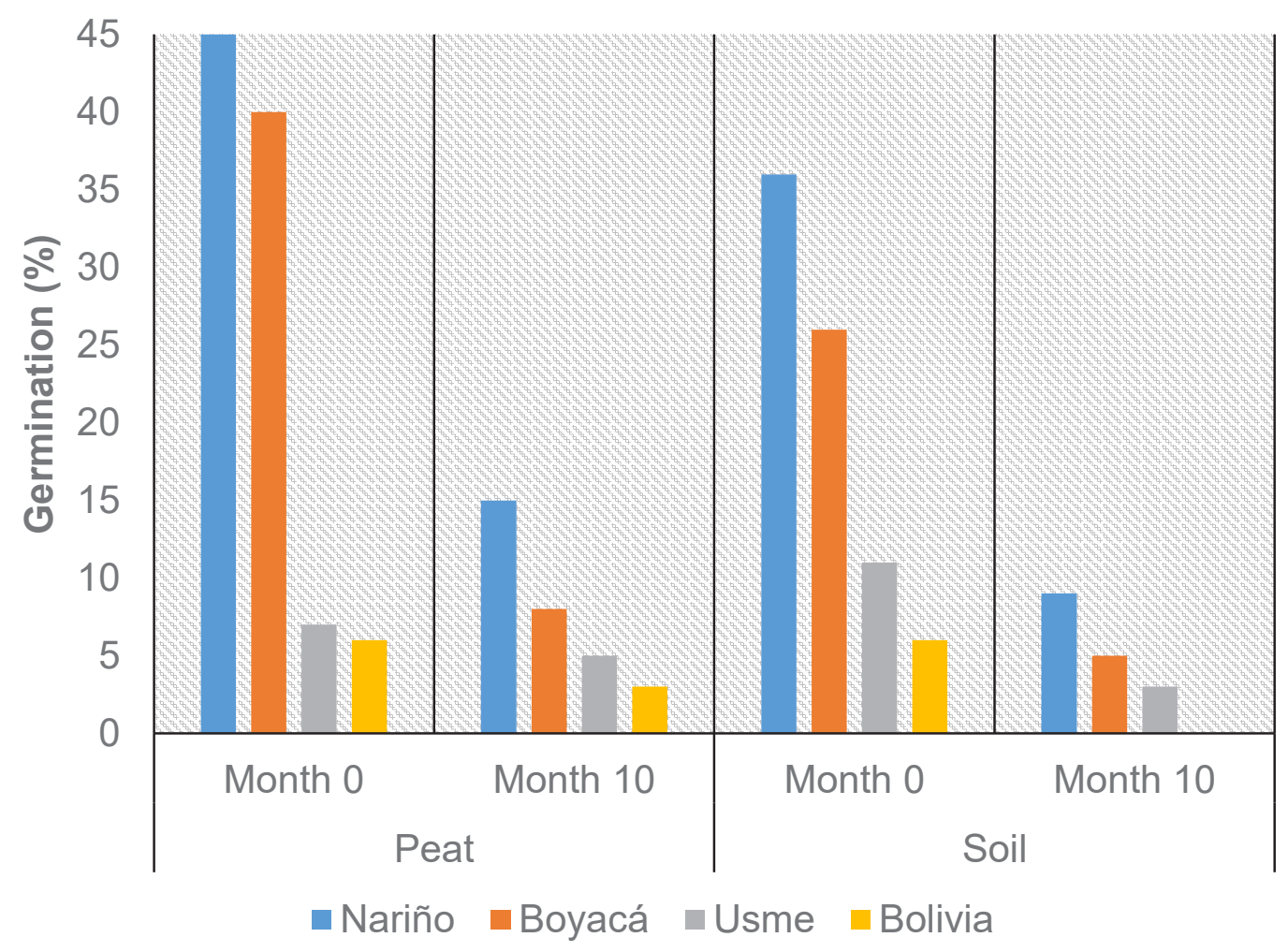

Figure 5. Behavior of quinoa seeds under ambient temperature conditions at the beginning of the evaluation and after ten months (Month 0 and 10, respectively).

\section{REFERENCES}

1. ABUGOCH JAMES, L.E. 2009. Quinoa (Chenopodium quinoa Willd.): composition, hemistry, nutritional, and functional properties. Adv. Food Nutr. Res. 58:1-31. https://doi.org/10.1016/S1043-4526(09)58001-1

2. ALMEIDA, F. de A.C.; FONSECA, K.S.; GOMES DE GOUVEIA, J.P. 1999. Influência da embalagem e do local de armazenamento na qualidade fisiológica de semestes de gergelim. Rev. Bras. Engenharia Agrícola e Ambiental. 3(2):195-201.

3. ANTUNA, O.; RINCÓN, F.; GUTIERREZ, E.; RUIZ, N.; BUSTAMANTE, L. 2003. Componentes genéticos de caracteres agronómicos y de calidad fisiológica de semillas en líneas de maíz. Fitotecnia Mexicana. 26(1):11-17.

4. APAZA, V.; CACERES, G.; ESTRADA, R.; PINEDO, R. 2013. Catálogo de variedades comerciales de quinua en el Perú: Instituto Nacional de Innovación Agraria (INIA). p.15-82.

5. CALLE, M.; AGUIRRE, G.; UGARTE, M.L.; UGARTE, L.; GABRIEL, J. 2010. Efecto del método de secado y nivel de humedad en la germinación y vigor de semillas de quinua. Rev. Agricultura. 62(49):10-15.

6. CECCATO, D.; BERTERO, H.D.; BATLLA, D. 2011. Fuentes de tolerancia al brotado pre-cosecha en quínoa (Chenopodium quinoa Willd.) efecto de las condiciones ambientales sobre el nivel de dormición. Comunicación técnica. Análisis de semillas [Rosario], 5(17):50-55.

7. CECCATO, D.; DELATORRE-HERRERA, J.; BURRIEZA, H.; BERTERO, D.; MARTÍNEZ, E.; DELFINO, I.; CASTELLIÓN, M. 2013. Fisiología de las semillas y respuesta a las condiciones de germinación. Capítulo 2.2. In: Bazile, D., Bertero, D., Nieto, C. (eds). Estado del arte de la quinua en el mundo en 2013. FAO (Santiago de Chile) y CRIAD, (Montepellier, Francia). p.153-166. 
8. CASTELLIÓN, M.; MATIACEVICH, S.; BUERA P.; MALDONADO, S. 2010. Protein deterioration and longevity of quinoa seeds during long-term storage. Food Chemistry. 121:952-958. https://doi.org/10.1016/j. foodchem.2010.01.025.

9. CATUINDA ARAGÃO, P.H.; VIEIRA DUARTE, H.; FERREIRA DA SILVA, R.; POSSE P., S.C. 2003. Influência do teor de água, da embalagem e das condições de armazenamiento na qualidades de sementes de maracujá aramelo. Rev. Brasileira de Sementes. 25(1):65-71.

10. DORIA, J. 2010. Generalidades sobre las semillas: su producción, conservación y almacenamiento. Cultivos Tropicales. 31(1):74-85.

11. ELLIS, R.H.; HONG, T.D.; JACKSON, M.T. 1993. Seed production environment, time of harvest, and the potential longevity of seeds of three cultivars of rice (Oryza sativa L.). Ann. Bot. 72:583-590. https://doi. org/10.1006/anbo.1993.1148

12. ELLIS, R.H.; HONG, T.D.; ROBERTS, E.H.; TAO, K.-L. 1990. Low moisture content limits to relations between seed longevity and moisture. Annals of Botany. 65:493-504. https://org.doi/10.1093/oxfordjournals.aob.a087961

13. ELLIS, R.H.; HONG, T.D.; ROBERTS, E.H. 1988. A low-moisture-content limit to logarithmic relations between seed moisture content and longevity. Ann. Bot. 61(4):405-408. https://doi.org/10.1093/oxfordjournals.aob.a087571

14. FILHO, A.M.M.; PIROZI, M.R.; BORGES, J.T.D.S.; PINHEIRO SANT'ANA, H.M.; CHAVES, J.B.P.; COIMBRA, J.S.D.R. 2017. Quinoa: Nutritional, functional, and antinutritional aspects. Critical Reviews in Food Science and Nutrition. 57(8):1618-1630. https://doi. org/10.1080/10408398.2014.1001811

15. GÓMEZ-TEJERO, J.; JASSO-MATA, J.; VARGASHERNÁNDEZ, J.J.; SOTO HERNÁNDEZ, M.R, 2006. Deterioro de semilla de dos procedencias de Swietenia macrophylla King, bajo dinstintos métodos de almacenamiento. Ra Ximhai. 2(1):223-239.

16. GUBLER, F.; MILLAR, A.A.; JACOBSEN, J.V. 2005. Dormancy release, $A B A$ and pre-harvest sprouting. Current Opinion in Plant Biology. 8(2):183-187. https:// doi.org/10.1016/j.pbi.2005.01.011 M
17. HARTMANN, H.T.; KESTER, D.E.; DAVIES, F.T.; GENEVE, R. 2011. Hartmann \& Kester's Plant Propagation: Principles and Practices. Eighth Ed., Prentice Hall/Pearson. 915p.

18. JUSTICE, O.L.; BASS, L.N. 1978. Principles and practices of seed storage. Washington, DC: US Government Printing Office. U.S. States Department Agriculture. Agriculture Handbook. No. 506. 296p.

19. KERMODE, A. 2005. Role of abscisic acid in seed dormancy. J. Plant Growth Regul. 24:319-344. https:// doi.org/10.1007/s00344-005-0110-2.

20. MAGNITSKIY, S.V.; PLAZA, G.A. 2007. Fisiología de semillas recalcitrantes de árboles tropicales. Agronomía Colombiana. 25(1):96-103.

21. MONTOYA, L.A.; MARTÍNEZ VIANCHÁ, L.; PERALTA BALLESTEROS, J. 2005. Análisis de variables estratégicas para la conformación de una cadena productiva de quinua en Colombia. Innovar. 15(25):103119.

22. MUÑOZ, R.; ACEVEDO, E. 2002. Evaluación del rendimiento potencial y bajo estrés hídrico de 11 genotipos de Quínoa (Chenopodium quinoa Willd.). Laboratorio Relación suelo-agua-planta. Facultad de Ciencias Agronómicas, Universidad de Chile. 46p.

23. MÚJICA, A.; JACOBSEN, S. 2006. La quinua (Chenopodium quinoa Willd.) y sus parientes silvestres. Botánica Económica de los Andes Centrales. 32:449457.

24. NAVRUZ-VARLI, S.; SANLIER, N. 2016. Nutritional and health benefits of quinoa (Chenopodium quinoa Willd.). J. Cereal.Sci. 69:371-376. https://doi. org/10.1016/j.jcs.2016.05.004

25. ORGANIZACIÓN DE LAS NACIONES UNIDAS PARA LA ALIMENTACIÓN Y LA AGRICULTURA -FAO-. 2010. El segundo informe sobre el estado de los recursos fitogenéticos para la alimentación y la agricultura en el mundo. Italia: FAO.

26. ROBERTS, E.H.; ELLIS, R.H. 1989. Water and Seed Survival. Ann. Bot. 63:9-52.

27. ROJAS, W.; PINTO, M.; CAMARGO, A. 2003. Estandarización de listas de descriptores de quinua y cañahua. En: Informe Técnico Anual 2002 - 2003. Año 2. Proyecto IPGRI-FAD "Elevar la contribución que 
hacen las especies olvidadas y subutilizadas a la seguridad alimentaria y a los ingresos de la población rural de escasos recursos". Fundación PROINPA, La Paz, Bolivia. p.59-94.

28. ROJAS, W.; PINTO, M.; ALANOCA, C.; PANDO, L.; LEÓN-LOBOS, P.; DIULGHEROFF, S.; PADULOSI, S.; BAZILE, D. 2013. Estado de la conservación ex situ de los recursos genéticos de quinua. Capítulo 1.5. In: Bazile, D.; Bertero, D.; Nieto, C. (eds). Estado del arte de la quinua en el mundo en 2013. FAO (Santiago de Chile) y CRIAD, (Montepellier, Francia). p.65-94.

29. ROSA, M.; HILAL, M.; GONZALEZ, J.A.; PRADO, F.E. 2009 .Low-temperature effect on enzyme activities involved in sucrose-starch partitioning in salt-stressed and salt-acclimated cotyledons of quinoa (Chenopodium quinoa Willd.) seedlings. Plant physiology and biochemistry. 47:300-307. https://doi.org/10.1016/j. plaphy.2008.12.001

30. SPEHAR, C.R.; SANTOS, R.L.B. 2002. Quinoa BRS Piabiru: alternative for diversification of cropping systems. Pesquisa Agropecuária Brasileira. 37(6):809-893. http://dx.doi.org/10.1590/S0100204X2002000600020

31. STRENSKE, A.; SOARES DE VASCONCELOS, E.; EGEWARTH, V., A.; MICHELON HERZOG, N.F.; DE MATOS MALAVASI, M. 2017. Responses of quinoa
(Chenopodium quinoa Willd.) seeds stored under different germination temperatures. Acta Scientiarum. Agronomy. 39(1):83-88. http://doiorg/10.4025/ actasciagron.v39i1.30989

32. TORRES, S.B.; APARECIDA, M.; DA SILVA, S.; RAMOS, S.R.R.; ABÍLIO, M.; QUEIROZ, D. 2002. Qualidade de sementes de maxixe armazenadas em diferentes embalagens e ambientes. Ciencias Agroecologica. 26(3):539-544.

33. VARGAS, D.E.; BOADA, M.; ARACA, L.; VARGAS, W.; VARGAS, R. 2015. Agrobiodiversidad y economía de la quinua (Chenopodium quinoa) en comunidades Aymaras de la cuenca del Titicaca. Idesia. 33(4):8187.

34. VILCACUNDO, R.; HERNÁNDEZ, B. 2017. Nutritional and biological value of quinoa (Chenopodium quinoa Willd.). Current Opinion in Food Science.14:1-6. https://doi.org/10.1016/j.cofs.2016.11.007

35. WALTERS, C.; WHEELER, L.; STANWOOD, P.C. 2004. Longevity of cryogenically stored seeds. Cryobiology. 48:229-244. https://doi.org/10.1016/j.cryobiol.2004.01.007

Received: September 5, 2018

Accepted: November 16, 2018

How to cite:

Romero, G.; Heredia, A.; Chaparro-Zambrano, H.N. 2018. Germinative potential in quinoa (Chenopodium quinoa Willd.) seeds stored under cool conditions. Rev. U.D.C.A Act. \& Div. Cient. 21(2):341-350. https://doi.org/10.31910/rudca.v21. n2.2018.1076 